\title{
HI F-1alpha in lung carcinoma: Histopathological evidence of hypoxia targets in patient biopsies
}

\author{
Maria I oannou ${ }^{1}$, George Simos ${ }^{2}$, George K Koukoulis ${ }^{1}$ \\ 1. Department of Pathology, University of Thessaly, School of Medicine, Biopolis, Larissa, Greece. 2. Laboratory of \\ Biochemistry, University of Thessaly, School of Medicine, Biopolis, Larissa, Greece \\ Correspondence: Maria I oannou. Address: Department of Pathology, University of Thessaly, School of Medicine, \\ Biopolis, Larissa 41110, Greece. E-mail: mioan@med.uth.gr
}

Received: December 3, 2012 Accepted: January 25, 2013

Online Published: February 20, 2013

DOI : $10.5430 /$ jst.v3n2p35

URL: http://dx.doi.org/10.5430/jst.v3n2p35

\section{Abstract}

Background: Hypoxia inducible factor 1alpha (HIF-1alpha) plays a major role in the response of tumors to hypoxia, and contributes to tumor aggressiveness, invasiveness and resistance to radiotherapy and chemotherapy. Targeting HIF-1alpha is an attractive strategy, with the potential for disrupting multiple pathways crucial for tumor growth. Thus, the evaluation of HIF-1alpha in patient biopsies could be useful in personalized cancer treatment.

Methodology: The current literature on HIF-1alpha immunohistochemical expression is reviewed along with the relation to clinical outcome and prognosis. In addition, the significant correlation of HIF-1alpha to vascular endothelial growth factor (VEGF) expression is reported, as well as the possible role of HIF-1alpha in predicting the therapeutic response to anti-EGFR therapies.

Conclusion: Herein, an overview of the HIF-1alpha expression in lung carcinoma is presented. Since there is no consensus regarding the assessment of HIF-1alpha in tissue specimens, heterogeneous results have been reported especially regarding prognosis. In this context, methods to optimize the evaluation of HIF-1alpha in biopsies are needed in order to clarify the role of HIF-1alpha as a prognostic or predictive biomarker in lung carcinoma.

\section{Key words}

Lung carcinoma, Hypoxia, HIF-1alpha, Immunohistochemistry

\section{I ntroduction}

Lung cancer is the leading cause of cancer deaths in USA and worldwide. The two major forms of lung cancer are nonsmall cell lung cancer (NSCLC, about $85 \%$ of all lung cancers) and small-cell lung cancer (SCC, about 15\%). Despite advances in early detection and standard treatment, lung carcinoma is often diagnosed at an advanced stage and has a poor prognosis ${ }^{[1,2]}$.

A common characteristic of all solid tumors is hypoxia, a condition under which proliferating tumor cells are deprived of oxygen due to a limited blood supply caused by abnormal tumor microvasculature ${ }^{[3]}$. However, hypoxic cancer cells show 
a range of genetic changes that improve survival, they continue to proliferate, are associated with a more invasive and metastatic phenotype and are usually resistant to conventional treatments such as radiotherapy and chemotherapy ${ }^{[4-6]}$.

The impact of hypoxia on cellular biology has been presented by the concept of the "hypoxia signature" which consists of a hypoxia-regulated gene cluster ${ }^{[7]}$. The major component of hypoxia signaling in the cell is the hypoxia-inducible factor (HIF) transcriptional complex ${ }^{[8]}$. Overexpression of HIF-alpha, the regulatory subunit of HIF, is associated with increased vascularity, severity of tumor grade, treatment failure and a poor prognostic outcome with conventional therapies. Therefore HIF is an attractive therapeutic target, and several different strategies have been developed to target HIF in recent years ${ }^{[9]}$.

This review outlines the current evidence on the role of Hypoxia-inducible factor 1 (HIF-1) and especially its subunit HIF-1alpha in biopsies of lung carcinoma. Histopathological evidence of HIF-1alpha expression is presented along with the possible involvement in prognosis and tumor progression. In addition, the immunohistochemical methodology of evaluating HIF-1alpha in tumor specimens is discussed.

\section{Tumor hypoxia}

Tumor growth is a process demanding a constant supply of nutrients and oxygen in order to be maintained. This supply is mainly achieved via angiogenesis ${ }^{[10,11]}$. However, the tumor growth often outruns the existing supply rate, with development of hypoxic areas, acidosis and nutrient starvation ${ }^{[12]}$.

In response to hypoxia, tumor cells and their corresponding environment express regulatory factors capable of protecting from the energy depletion, leading to apoptosis or necrosis. These factors are the commonest indirect way of identifying hypoxia in tissues ${ }^{[13]}$. Hypoxia can be directly measured by intervention techniques, measuring intratumoral $\mathrm{PO}_{2}{ }^{[13]}$ although, such an approach is limited to experimental settings.

The most studied hypoxia-related factors are the hypoxia inducible factors (HIFs) ${ }^{[14]}$. HIF activity is deregulated in many human cancers, and this is most commonly due to the overexpression of HIF-alpha, the regulatory subunit of the HIF complex even under normoxic conditions. Overexpression of HIF-alpha is usually associated with neoangiogenesis, higher tumor grade, treatment failure and a poor clinical outcome ${ }^{[15-18]}$, with HIF-1 being considered as a candidate biological predictor for tumor cell response to treatment. Additionally, in vitro and in vivo studies have shown that HIFs could be targets of molecular therapy ${ }^{[6,9]}$.

\subsection{HIF-1alpha}

Tumor hypoxia results in the stabilization of the HIF family of transcription factors. The prototype of the family is HIF-1. HIF-1 is a heterodimeric transcription factor. It comprises an alpha and a beta subunit ${ }^{[8]}$. While HIF-1beta is constantly expressed, HIF-1alpha intracellular concentrations vary as a result of hypoxic conditions ${ }^{[16]}$.

In normoxia, HIF-1alpha is hydroxylated ${ }^{[16,19]}$ to become target for proteolysis in proteosomes ${ }^{[13,16]}$. Additionally, an oxygen-dependent asparaginyl hydroxylase called factor inhibiting HIF-1 (FIH) represses the transactivational ability of HIF-1 ${ }^{[20]}$. In contrast, under hypoxic conditions, HIF-1alpha escapes from proteolysis ${ }^{[13,16]}$. The accumulated HIF-1alpha binds to HIF-1beta, assembling the active HIF-1 which then acts as a transcription factor binding to specific hypoxia response elements (HRE) inducing transcription of its target genes ${ }^{[8,16]}$. The genes activated by activated HIF-1 are involved in the uptake and metabolism of glucose, erythropoiesis, angiogenesis, regulation of extracellular $\mathrm{pH}$, cell cycle regulation, apoptosis, and mitogenesis ${ }^{[7,8,14,16]}$. Finally, HIF-1 is suggested to be a factor related with cancer invasion and metastasis $^{[21]}$. 
HIF-1alpha expression and activity can be also controlled by oxygen-independent mechanisms activated by oncogenes (such as EGFR, RAS and BRAF) or growth factors that stimulate the MAPK, mTOR and PI-3K/Akt pathways ${ }^{[22,23,24]}$.

\subsection{HI F-1alpha in lung cancer}

The literature for HIF-1alpha expression in lung carcinoma was systematically reviewed using the terms "hypoxia inducible factor AND lung carcinoma" OR "HIF AND lung carcinoma", from 1991 to 2012. Despite the increasing interest in hypoxia regarding carcinomas of different origin, the relevant literature was not extensive. The inclusion criteria were: a) evaluation of lung cancer prognosis based on HIF-1alpha expression and b) application of immunohistochemistry. The main details of the studies focusing on HIF-1alpha in lung carcinoma are demonstrated in Table 1.

Table 1. Presentation of the studies regarding lung carcinoma, assessing HIF-1alpha with immunohistochemistry

\begin{tabular}{|c|c|c|c|}
\hline Reference & Sample size/type & HIF-1alpha related remarks & $\begin{array}{l}\text { Significant association } \\
\text { with adverse outcomes }\end{array}$ \\
\hline $\begin{array}{l}\text { Swinson et al } \\
2004^{[35]}\end{array}$ & 172/ NSCLC & $\begin{array}{l}\text { High levels of expression are associated with a poor prognosis. Epidermal } \\
\text { growth factor receptor expression was closely associated with HIF-1alpha }\end{array}$ & Yes \\
\hline $\begin{array}{l}\text { Giatromanolaki } \\
2001^{[28]}\end{array}$ & 108/ NSCLC & HIF-1 apha was not identified as an independent prognostic indicator & No \\
\hline $\begin{array}{l}\text { Kim et al } \\
2005^{[37]}\end{array}$ & 74/ NSCLC & $\begin{array}{l}\text { Expression of HIF-1alpha and CA IX was significantly associated with } \\
\text { shorter disease free survival. HIF-1alpha was not an independent prognostic } \\
\text { indicator }\end{array}$ & No \\
\hline $\begin{array}{l}\text { Hung et al } \\
2009^{[31]}\end{array}$ & 87/ NSCLC & $\begin{array}{l}\text { Overexpression of HIF-1alpha was associated with a shorter recurrence-free } \\
\text { survival }\end{array}$ & Yes \\
\hline $\begin{array}{l}\text { Wu et al } \\
2011^{[30]}\end{array}$ & 140/ NSCLC & HIF-1alpha, was not related to poor outcome & No \\
\hline $\begin{array}{l}\text { Volm et al } \\
2000^{[38]}\end{array}$ & 96/ NSCLC & $\begin{array}{l}\text { Patients with HIF-positive carcinomas had significantly longer median } \\
\text { survival times than patients with HIF-negative carcinomas }\end{array}$ & No \\
\hline $\begin{array}{l}\text { Ioannou et al } \\
2009^{[34]}\end{array}$ & $30 / \mathrm{SCC}$ & $\begin{array}{l}\text { HIF-1 alpha expression was significantly correlated with VEGF expression } \\
\text { HIF-1alpha/ VEGF double positive tumors were associated with poor } \\
\text { survival }\end{array}$ & No \\
\hline $\begin{array}{l}\text { Enatsu et al } \\
2006^{[39]}\end{array}$ & 78/ NSCLC & HIF-1alpha is associated with VEGF expression and poor prognosis & Yes \\
\hline $\begin{array}{l}\text { Giatromanolaki } \\
2001^{[40]}\end{array}$ & 107/ NSCLC & $\begin{array}{l}\text { HIF-1alpha is associated with carbonic anhydrase } 9 \text { expression which is an } \\
\text { independent prognostic indicator }\end{array}$ & N/A \\
\hline $\begin{array}{l}\text { Yohena et al } \\
2009^{[44]}\end{array}$ & 66/ NSCLC & $\begin{array}{l}\text { The level of HIF-1alpha mRNA showed a significantly positive correlation } \\
\text { with the mRNA levels of vascular endothelial growth factor and it is } \\
\text { associated with disease progression in NSCLC }\end{array}$ & Yes \\
\hline $\begin{array}{l}\text { Wan et al } \\
2011^{[46]}\end{array}$ & SCC cell line & $\begin{array}{l}\text { HIF-1alpha significantly promotes the growth and angiogenesis of SCC cell } \\
\text { lines by upregulating the expression of angiogenic genes }\end{array}$ & N/A \\
\hline $\begin{array}{l}\text { Andersen et al } \\
2011^{[36]^{*}}\end{array}$ & 335/ NSCLC & $\begin{array}{l}\text { Coexpression of HIF-1alpha and NOTCH-1 is significantly indicative for } \\
\text { poor prognosis }\end{array}$ & No \\
\hline $\begin{array}{l}\text { Peng et al } \\
2009^{[29]^{*}}\end{array}$ & 80/ NSCLC & $\begin{array}{l}\text { The positive rate of HIF-1alpha was significantly higher in lung cancer than } \\
\text { that in normal lung tissues }\end{array}$ & Yes \\
\hline $\begin{array}{l}\text { Zuo et al } \\
2008^{[41]}\end{array}$ & 48/ NSCLC & HIF-1alpha and VEGF-C work synergically in the process of NSCLC & Yes \\
\hline $\begin{array}{l}\text { Karetsi et al } \\
2012^{[27]}\end{array}$ & 33NSCLC, $22 \mathrm{SCC}$ & $\begin{array}{l}\text { The expression of HIF-1alpha differs significantly between SCC and } \\
\text { NSCLC of lung cancer. HIF-1alpha expression is significantly associated } \\
\text { with VEGF expression in both types of lung carcinoma }\end{array}$ & N/A \\
\hline $\begin{array}{l}\text { Wan et al } \\
2009^{[47]}\end{array}$ & SCC cell line & $\begin{array}{l}\text { HIF-1alpha effects on genes expression profile of SCC. HIF-1alpha } \\
\text { antagonistic effect on SOCS1 regulation of growth and apoptosis }\end{array}$ & N/A \\
\hline $\begin{array}{l}\text { Zhou et al } \\
2011^{[26]^{*}}\end{array}$ & NSCLC cell line & Inhibition of both HIF-1 and HIF-2 prevents tumor colonization & N/A \\
\hline $\begin{array}{l}\text { Park et al } \\
2011^{[51]}\end{array}$ & 178/ NSCLC & $\begin{array}{l}\text { HIF-1alpha was a significant worse prognostic factor for overall survival in } \\
\text { patients with low EGFR gene copy number and negative EGFR expression }\end{array}$ & Yes \\
\hline
\end{tabular}

*Reference not used in the current review

N/A, not applicable 
Recent studies using genetically engineered mouse models expressing stabilized HIF delineate its importance in the evolution of NSCLC angiogenesis and tumor progression and demonstrate genetically that HIF is causally involved in NSCLC. Experimental studies concluded that treatment with HIF-1alpha antagonists inhibited the progression and spread of both NSCLC and SCC in mice ${ }^{[25]}$. Moreover, agents that target HIF-1, renders tumour cells more susceptible to radiotherapy and conventional chemotherapeutic agents and further delay tumor regrowth in cell lines ${ }^{[17,18]}$. In this context, the demonstration of HIF-1alpha "status" in biopsies from patients with lung carcinoma has been considered as possibly helpful in identifying hypoxia induced targets in tumor.

Systematic review of the relevant literature revealed immnohistochemical studies of HIF-1alpha expression mainly in biopsies from patients with NSCLC. Although there are very limited data regarding HIF-1alpha in SCC, however, HIF-1alpha is found to be expressed in both types of lung carcinoma albeit possibly to a different extent ${ }^{[27]}$.

An early study reported HIF-1alpha protein overexpression in $62 \%$ of tissue samples from 108 patients with early stage resectable NSCLC ${ }^{[28]}$, while according to a more recent tissue microarray study high HIF-1alpha expression was reported in $35 \%$ of NSCLC cases ${ }^{[30]}$. On the other hand, retrospective analysis of 87 patients with resectable NSCLC showed, immunohistochemical overexpression of HIF-1alpha, was shown in $32.2 \%$ of primary tumors ${ }^{[31]}$. Regarding SCC, the expression of HIF-1alpha mRNA and protein expression was documented in SCC cell lines under hypoxia ${ }^{[32]}$, while two studies with immunohistochemical analysis of tissue specimens demonstrated HIF-1alpha protein expression in $66.7 \%{ }^{[33]}$ and $43 \%$ respectively ${ }^{[34]}$.

\subsection{HIF-1alpha and prognosis}

A number of HIF-1alpha immunohistochemical studies have provided statistically significant clinical correlations. However, regarding prognosis these studies show relatively heterogeneous results. From a pathological point of view, this could be attributed, at least in part, to differences in the mode of HIF-1alpha histopathological evaluation (see paragraph "HIF-1alpha evaluation in tissue specimens") and differences in the type of sample examined (bioptic or whole tumor). In NSCLC, high level of HIF-1 alpha expression was associated with a poor prognosis in a study including 172 patients with NSCLC ${ }^{[35]}$. On the other hand, a different study reported that HIF-1alpha expression was marginally associated with poor prognosis, whereas poor clinical outcome was correlated only with HIF-2alpha ${ }^{[28]}$. High level HIF-1alpha expression detected immunohistochemicaly was correlated with a decreased disease free survival in 74 early stage NSCLC patients ${ }^{[37]}$. Along the same line, a retrospective analysis of 87 patients with resectable NSCLC, showed that HIF-1alpha immunoexpression was associated with a shorter overall survival and with a shorter recurrence-free survival ${ }^{[31]}$.

In contrast, immunohistochemical expression of HIF-1alpha was suggested to have no impact on patient survival in a tissue microarray study including surgical specimens of 140 patients with NSCLC [30] and another study reported that among 96 patients with NSCLC, those with HIF-1 positive carcinomas had significantly longer median survival times than patients with HIF-1 negative carcinomas ${ }^{[38]}$. In the latter report, using multivariate analyses the authors demonstrated that the presence of HIF-1 at a given stage or extent of lymph node involvement is an independent prognostic factor for the survival of patients with non-small cell lung carcinomas ${ }^{[38]}$.

In respect to SCC, it was shown that double positive HIF-1alpha/ Vascular Endothelial Growth Factor (VEGF) cases were associated with poor survival ${ }^{[34]}$. However, large studies with big number of patients should be performed in order to investigate the precise role of HIF-1alpha immunoistochemical expression in SCC biopsies.

\subsection{HIF-1alpha and angiogenesis}

Upregulation of angiogenic pathways by HIF-1alpha has been seen in NSCLC and it is reported as a common event associated with poor prognosis ${ }^{[28,39-41]}$. 
Vascular endothelial growth factor (VEGF) and its receptors play critical roles in the development of tumor vasculature and can be targeted by agents such as bevacizumab in the treatment of NSCLC ${ }^{[42,43]}$. Furthermore, tumor hypoxia and the expression of the HIF family of proteins are also linked to poorer survival in these patients ${ }^{[42]}$. A significant correlation between HIF-1alpha and VEGF expression has been documented in protein as well as in mRNA level and it is associated with disease progression in NSCLC tissues ${ }^{[28,30,44]}$.

Recent studies have shown that the HIF-1alpha/VEGF angiogenic pathway may be active in SCC, similar to that in $\operatorname{NSCLC}^{[34,45,46,47]}$. Investigation of angiogenesis in a vivo experimental model concluded that HIF-1alpha significantly promotes the growth and angiogenesis of SCC cell lines by upregulating the expression of angiogenic genes ${ }^{[46]}$. Moreover, significant correlation between HIF-1alpha and VEGF immunohistochemical expression was found in SCC biopsies ${ }^{[34]}$. In the same study, a positive correlation between VEGF and VEGF-R2 expression was also detected suggesting a potential VEGF/VEGF-R2 autocrine pathway in SCC.

\subsection{HIF-1alpha and EGFR}

The Epidermal Growth Factor Receptor (erb1/EGFR), a member of the family of receptor tyrosine kinases, is overexpressed in $80 \%$ of NSCLC and mutated in a smaller percentage ${ }^{[1,48-50]}$. EGFR activation regulates important tumorigenic processes, including proliferation, apoptosis, angiogenesis, and invasion, and, along with its ligands, it is frequently correlated to the development and progression of NSLC. Clinical trials of the EGFR tyrosine kinase inhibitor erlotinib and of cetuximab, a monoclonal antibody against EGFR, validated EGFR as a molecular target for therapy ${ }^{[1]}$.

Different studies have demonstrated close association between the HIF-1alpha signaling pathways and epidermal growth factor receptors (EGFRs). The prognostic significance of HIF-1alpha expression was evaluated in 178 NSCLC patients using tissue microarray in the context of EGFR gene copy number and protein expression status ${ }^{[51]}$. The difference in overall survival between HIF-1 alpha-positive and HIF-1alpha-negative groups was statistically significant in patients with low EGFR gene copy number and negative EGFR expression. In univariate and multivariate analyses, HIF-1alpha was a significant worse prognostic factor for overall survival in patients with low EGFR gene copy number and negative EGFR expression. The results suggested that the gene and protein status of EGFR and HIF-1alpha will be important to select patients most likely to derive the greatest clinical benefit from EGFR or HIF-1alpha targeted therapies ${ }^{[51]}$.

In addition, downregulation of HIF-1alpha was associated with positive therapeutic responses of cancer cells to EGFR-targeted therapy and suggested further investigation using HIF-1alpha as an indicator of tumor response to EGFR-targeted therapy in preclinical studies and in the clinical setting ${ }^{[52]}$.

The above data indicate that if HIF-1alpha develops as a therapeutic target, consideration should be given to combining the novel anti-HIF-1alpha agents with anti-EGFR targeted drugs in NSCLC ${ }^{[53]}$.

\subsection{HI F-1alpha evaluation in tissue specimens}

Effective evaluation of hypoxia could be essential for cancer detection and diagnosis, assessment of therapy, as well as drug development. It could provide a prognostic and/or a predictive basis by which the effects of tumor hypoxia could be evaluated in personalised cancer treatment. Several direct and indirect methods for measuring hypoxia have been developed including sophisticated radiological imaging ${ }^{[6,54]}$. The development of Eppendorf polarographic probes has permitted the direct measurement of tumor hypoxia, however in accessible tumors. This method has been performed in 20 patients with early stage NSCLC. Low tumor/normal lung $\mathrm{PO}_{2}$ level ratios were associated with an increased risk of disease relapse ${ }^{[55]}$.

For histopathological examination of lung carcinoma biopsies, immunohistochemistry has been a common method of studying HIF-1alpha expression in tumor samples. However, there is controversy about the pattern of HIF-1a staining to be evaluated. HIF-1alpha was reported to be localized both in the nucleus and the cytoplasm of tumor cells. Some authors 
consider only nuclear staining as positive ${ }^{[31,34]}$ while others take into account cytoplasmic reactivity as well ${ }^{[28,30,39]}$. The presence and the biological significance of cytoplasmic HIF-1alpha staining in tissue samples are controversial. Recent studies suggest that, at least in cultured cancer cells, transport of HIF-1alpha between nucleus and cytoplasm and its subsequent subcellular distribution is a highly regulated process, linked to the activation status of the MAPK pathway and the proliferation state of the cells ${ }^{[56,57]}$. It is beyond the scope of this review to investigate the possible biological significance of cytoplasmic HIF-1alpha in tissue samples. However the nuclear localization of HIF-1alpha could be considered as a certain measure of HIF-1 activation; cytoplasmic HIF-1alpha cannot activate transcription and its presence may not be related to extent of the hypoxic response ${ }^{[13]}$. In this context, evaluation of cytoplasmic reactivity might lead to overestimations.

It is also of note that antibody selection has been largely limited to a few commercially available reagents and variation in HIF-1alpha immunoreactivity has been documented. This variation has been ascribed primarily, albeit conveniently, to alterations of tumor neovascularization and hypoxia. However, a recent comprehensive study has demonstrated that HIF-1alpha immunostaining might show significant 'antibody-dependent' variation ${ }^{[58]}$. Given the demand for reliable immunoassays and precision-oriented immunohistology which follows the increasing application of novel targeted therapies, it would be important to optimize the assessment of HIF- 1alpha expression in tissue specimens by using a panel of antibodies as well as controls with well characterized HIF-1alpha overexpressing cell lines. Additional validation of the immunoassay could be performed by including analysis of known downstream specific targets of HIF-1 as their upregulation is mainly due to HIF-1alpha pathway activation ${ }^{[58]}$.

\section{Conclusion}

Hypoxia is involved in lung cancer, with HIF-1 alpha being thoroughly studied. Current evidence supports the involvement of HIF-1alpha in carcinogenesis, tumor angiogenesis and cancer progression through the interaction of HIF-mediated pathways with other oncogenic signaling networks. Therefore, the combination of HIF inhibitors with existing treatments or other new targeted therapies may be very useful clinically. However, the development of appropriate methods to accurately measure hypoxia in tumors, as well as the establishment of consensus for HIF-1alpha evaluation in tissue samples, are needed in order to clarify the role of HIF-1alpha as a prognostic and predictive biomarker in lung carcinoma.

\section{References}

[1] Herbst RS, Heymach JV, Lippman SM. Lung cancer. N Engl J Med. 2008; 359(13): 1367-80. PMid:18815398 http://dx.doi.org/10.1056/NEJMra0802714

[2] Elias D Small cell lung cancer: state-of-the-art therapy in 1996. Chest. 1997; 112: 251S-258S. PMid:9337299 http://dx.doi.org/10.1378/chest.112.4_Supplement.251S

[3] Wilson WR, Hay MP Targeting hypoxia in cancer therapy. Nat Rev Cancer. 2011; 11: 393-410. PMid:21606941 http://dx.doi.org/10.1038/nrc3064

[4] Hockel M, Schlenger K, Aral B, Mitze M, Schaffer U, Vaupel P. Association between tumor hypoxia and malignant progression in advanced cancer of the uterine cervix. Cancer Res. 1996; 56: 4509-4515. PMid:8813149

[5] Hockel, M, Vaupel, P. Tumor hypoxia: definitions and current clinical, biologic, and molecular aspects. J Nat Cancer Instit. 2001; 93: 266-276. http://dx.doi.org/10.1093/jnci/93.4.266

[6] Poon E, Harris AL, Ashcroft M. Targeting the hypoxia-inducible factor (HIF) pathway in cancer. Expert Rev Mol Med. 2009; 11: e26. PMid:19709449 http://dx.doi.org/10.1017/S1462399409001173

[7] Chi JT, Wang Z, Nuyten DS, Rodriguez EH, Schaner ME, Salim A, Wang Y, Kristensen GB, Helland A, Borresen-Dale AL, Giaccia A, Longaker MT, Hastie T, Yang GP, van de Vijver MJ, Brown PO. Gene expression programs in response to hypoxia: cell type specificity and prognostic significance in human cancers. PLoS Med. 2006; 3: e47. PMid:16417408 http://dx.doi.org/10.1371/journal.pmed.0030047

[8] Semenza GL Hypoxia-inducible factors in physiology and medicine. Cell. 2012; 148: 399-408. PMid:22304911 http://dx.doi.org/10.1016/j.cell.2012.01.021 
[9] Semenza GL Hypoxia-inducible factors: mediators of cancer progression and targets for cancer therapy. Trends Pharmacol Sci. 2012; 33: 207-14. PMid:22398146 http://dx.doi.org/10.1016/j.tips.2012.01.005

[10] Folkman J. Role of angiogenesis in tumor growth and metastasis. Semin. Oncol. 2002; 29: 15-18. PMid:12516034

[11] Powis G, Kirkpatrick L. Hypoxia inducible factor-1alpha as a cancer drug target. Mol Cancer Ther. 2004; 3: 647-654. PMid:15141023

[12] Semenza GL Hypoxia-inducible factor 1 and cancer pathogenesis. IUBMB Life. 2008; 60: 591-597. PMid:18506846 http://dx.doi.org/10.1002/iub.93

[13] Seeber LM, Horree N, Vooijs MA, Heintz AP, van der Wall E, Verheijen RH, van Diest PJ. The role of hypoxia inducible factor-1alpha in gynecological cancer. Crit Rev Oncol Hematol. 2011; 78: 173-184. PMid:20627616 http://dx.doi.org/10.1016/j.critrevonc.2010.05.003

[14] GL Semenza. Oxygen Sensing, Homeostasis, and Disease N Engl J Med. 2011; 365: 537-547.

[15] Zhong H, De Marzo AM, Laughner E, Lim M, Hilton DA, Zagzag D, Buechler P, Isaacs WB, Semenza GL, Simons JW. Overexpression of hypoxiainducible factor-1alpha in common human cancers and their metastases. Cancer Res. 1999; 59: 5830-5835. PMid:10582706

[16] Ruan K, Song G, Ouyang G. Role of hypoxia in the hallmarks of human cancer. J. Cell Biochem. 2009; 107: $1053-1062$. PMid:19479945 http://dx.doi.org/10.1002/jcb.22214

[17] DeClerck K, Elble RC. The role of hypoxia and acidosis in promoting metastasis and resistance to chemotherapy. Front Biosci. 2010; 15: 213-225. http://dx.doi.org/10.2741/3616

[18] Moeller BJ, Dreher MR, Rabbani ZN, Schroeder T, Cao Y, Li CY, Dewhirst MW. Pleiotropic effects of HIF-1 blockade on tumor radiosensitivity. Cancer Cell. 2005; 8: 99-110. PMid:16098463 http://dx.doi.org/10.1016/j.ccr.2005.06.016

[19] Majmundar AJ, Wong WJ, Simon MC. Hypoxia-inducible factors and the response to hypoxic stress. Mol Cell. 2010 ; $40: 294-309$. PMid:20965423 http://dx.doi.org/10.1016/j.molcel.2010.09.022

[20] Lisy K, Peet DJ. Turn me on: regulating HIF transcriptional activity. Cell Death Differ. 2008; 15: 642-649. PMid:18202699 http://dx.doi.org/10.1038/sj.cdd.4402315

[21] Gort EH, Groot AJ, van der Wall E, van Diest PJ, Vooijs MA. Hypoxic regulation of metastasis via hypoxia-inducible factors. Curr Mol Med. 2008; 8: 60-67. PMid:18289014 http://dx.doi.org/10.2174/156652408783565568

[22] Blancher C, Moore JW, Robertson N, Harris AL. Effects of ras and VHL gene mutations on hypoxia-inducible factor (HIF)-1alpha, HIF-2alpha and vascular endothelial growth factor expression and their regulation by the PI3K/Akt signaling pathway. Cancer Res. 2001; 61: 7349-55. PMid:11585776

[23] Kumar SM, Yu H, Edwards R, Chen L, Kazianis S, Brafford P, Acs G, Herlyn M, Xu X. Mutant V600E BRAF increases hypoxia inducible factor-1alpha expression in melanoma. Cancer Res. 2007; 67: 3177-84. PMid:17409425 http://dx.doi.org/10.1158/0008-5472.CAN-06-3312

[24] O’Donnell JL, Joyce MR, Shannon AM, Harmey J, Geraghty J, Bouchier-Hayes D. Oncological implications of hypoxia inducible factor-1alpha (HIF-1alpha) expression. Cancer Treat Rev. 2006; 32: 407-416. PMid:16889900 http://dx.doi.org/10.1016/j.ctrv.2006.05.003

[25] Jacoby JJ, Erez B, Korshunova MV, Williams RR, Furutani K, Takahashi O, Kirkpatrick L, Lippman SM, Powis G, O'Reilly MS, Herbst RS. Treatment with HIF-1alpha antagonist PX-478 inhibits progression and spread of orthotopic human small cell lung cancer and lung adenocarcinoma in mice.J Thorac Oncol. $2010 \mathrm{Jul}$; 5(7): 940-9. PMid:20512076

[26] Zhou Q, Chen T, Ibe JCF, Usha Raj J, Zhou G. Loss of either HIF 1or 2 promotes lung cancer colonization. Cell Cycle. 2011; 10: 2233-4. http://dx.doi.org/10.4161/cc.10.13.16307

[27] Karetsi E, Ioannou M, Kerenidi T, Minas M, Molyvdas PA, Gourgoulianis KI, Praskeva E. Differential expression of Hypoxia Inducible Factor-1alpha in non-small cell lung cancer and small cell lung cancer. Clinics. 2012; 67(12). http://dx.doi.org/10.6061/clinics/2012(12)05

[28] Giatromanolaki A, Koukourakis MI, Sivridis E, Turley H, Talks K, Pezzella F, Gatter KC, Harris AL. Relation of hypoxia inducible factor 1 alpha and 2 alpha in operable non-small cell lung cancer to angiogenic/molecular profile of tumours and survival. Br J Cancer. 2001; 85(6): 881-90. PMid:11556841 http://dx.doi.org/10.1054/bjoc.2001.2018

[29] Peng Z, Shan C, Wang H. Expression of VHL and HIF-1 alpha and its clinical significance in the lung cancer tissue. Zhong Nan Da Xue Bao Yi Xue Ban. 2009; 34(4): 331-4.

[30] Wu XH, Qian C, Yuan K. Correlations of hypoxia-inducible factor-1 $\alpha$ /hypoxia-inducible factor-2 $\alpha$ expression with angiogenesis factors expression and prognosis in non-small cell lung cancer. Chin Med J (Engl). 2011 Jan; 124(1): 11-8.

[31] Hung JJ, Yang MH, Hsu HS, Hsu WH, Liu JS, Wu KJ. Prognostic significance of hypoxia-inducible factor-1alpha, TWIST1 and Snail expression in resectable non-small cell lung cancer. Thorax. 2009; 64(12): 1082-9. PMid:19778933 http://dx.doi.org/10.1136/thx.2009.115691 
[32] Munksgaard Persson M, Johansson ME, Monsef N, Planck M, Beckman S, Seckl MJ, Ronnstrand L, Pahlman S, Pettersson HM. HIF-2a expression is suppressed in SCLC cells, which survive in moderate and severe hypoxa when HIF-1alpha is repressed. Am J Pathol. 2012; 180(2): 494-504. PMid:22115707 http://dx.doi.org/10.1016/j.ajpath.2011.10.014

[33] Fan LF, Diao LM, Chen DJ, Liu MQ, Zhu LQ, Li HG, Tang ZJ, Xia D, Liu X, Chen HL. Expression of HIF-1 alpha and its relationship to apoptosis and proliferation in lung cancer. Ai Zheng. 2002; 21: 254-258. PMid:12451989

[34] Ioannou M, Papamichali R, Kouvaras E, Mylonis I, Vageli D, Kerenidou T, Barbanis S, Daponte A, Simos G, Gourgoulianis K, Koukoulis GK: Hypoxia inducible factor-1 alpha and vascular endothelial growth factor in biopsies of small cell lung carcinoma. Lung. 2009; 187: 321-9. PMid:19707816 http://dx.doi.org/10.1007/s00408-009-9169-z

[35] Swinson DE, Jones JL, Cox G, Richardson D, Harris AL, O'Byrne KJ. Hypoxia-inducible factor-1 alpha in non-small cell lung cancer: relation to growth factor, protease and apoptosis pathways. Int J Cancer. 2004; 111(1): 43-50. PMid:15185341 http://dx.doi.org/10.1002/ijc.20052

[36] Andersen S, Donnem T, Al-Saad S, Al-Shibli K, Stenvold H, Busund LT, Bremnes RM. Correlation and coexpression of HIFs and NOTCH markers in NSCLC. Anticancer Res. 2011; 31(5): 1603-6. PMid:21617216

[37] Kim SJ, Rabbani ZN, Dewhirst MW, Vujaskovic Z, Vollmer RT, Schreiber EG, Oosterwijk E, Kelley MJ.Expression of hIF-1alpha, CAIX, VEGF, and MMP-9 in surgically resected non-small cell lung cancer. Lung Cancer. 2005; 49: 325-35. PMid:15935515 http://dx.doi.org/10.1016/j.lungcan.2005.03.036

[38] Volm M, Koomägi R. Hypoxia-inducible factor (HIF-1) and its relationship to apoptosis and proliferation in lung cancer. Anticancer Res. 2000; 20(3A): 1527-33. PMid:10928066

[39] Enatsu S, Iwasaki A, Shirakusa T, Hamasaki M, Nabeshima K, Iwasaki H, Kuroki M, Kuroki M. Expression of hypoxia inducible factor-1 alpha and its prognostic significance in non-small-sized adenocarcinomas of the lung. Eur J Cardiothorac Surg. 2006; 29: 891-895. PMid:16675263 http://dx.doi.org/10.1016/j.ejcts.2006.03.027

[40] Giatromanolaki A. Prognostic role of angiogenesis in non-small cell lung cancer. Anticancer Res. 2001; 21(6B): 4373-82. PMid:11908693

[41] Zuo S, Ji Y, Wang J, Guo J. expression and clinical implication of HIF-1alpha and VEGF-C in NSCLC. J Huazhong Univ Sci Technolog Med Sci. 2008; 28(6): 674-6. PMid:19107364 http://dx.doi.org/10.1007/s11596-008-0613-8

[42] Jackson AL, Zhou B, Kim WY. HIF, hypoxia and the role of angiogenesis in non-small cell lung cancer. Expert Opin Ther Targets. 2010; 14(10): 1047-1057. PMid:20854179 http://dx.doi.org/10.1517/14728222.2010.511617

[43] Pallis AG, Syrigos KN. Targeting tumor neovasculature in non-small-cell lung cancer. Crit Rev Oncol Hematol. 2012 Nov 15. doi:pii: S1040-8428(12)00209-0. 10.1016/j.critrevonc.2012.10.003. [Epub ahead of print]

[44] Yohena T, Yoshino I, Takenaka T, Kameyama T, Ohba T, Kuniyoshi Y, Maehara Y. Upregulation of hypoxia-inducible factor-1alpha mRNA and its clinical significance in non-small cell lung cancer. J Thorac Oncol. 2009 Mar; 4(3): 284-90. PMid:19190516 http://dx.doi.org/10.1097/JTO.0b013e31819852d5

[45] Pedersen MW, Holm S, Lund EL, Hojgaard L, Kristjansen PE. Coregulation of glucose uptake and vascular endothelial growth factor (VEGF) in two small-cell lung cancer sublines in vivo and in vitro. Neoplasia. 2001; 3: 80-87. PMid:11326319 http://dx.doi.org/10.1038/sj.neo.7900133

[46] Wan J, Chai H, Yu Z, Ge W, Kang N, Xia W, Che Y. HIF-1a effects on angiogenic potential in human small cell lung carcinoma. J Exp Clin Cancer Res. 2011; 30: 77. PMid:21843314 http://dx.doi.org/10.1186/1756-9966-30-77

[47] Wan J, Ma J, Mei J, Shan G. The effects of HIF-1alpha on gene expression profiles of NCI H446 human small cell lung cancer cells. J Exp Clin cancer Res. 2009; 28: 150. PMid:20003295 http://dx.doi.org/10.1186/1756-9966-28-150

[48] Berardi R, Santinelli A, Brunelli A, Onofri A, Pierantoni C, Scartozzi M, Pisa E, Stramazzotti D, Mazzanti P, Zuccatosta L, Gasparini S, Sabbatini A, Cascinu S. Epidermal growth factor receptor status in stages of resected non-small cell lung cancer: implications for treatment with epidermal growth factor receptor inhibitors. Anal Quant Cytol Histol. 2011; 33(4): 196-204. PMid:21980623

[49] Ellis PM, Blais N, Soulieres D, Ionescu DN, Kashyap M, Liu G, Melosky B, Reiman T, Romeo P, Shepherd FA, Tsao MS, Leighl NB. A systematic review and Canadian consensus recommendations on the use of biomarkers in the treatment of non-small cell lung cancer. J Thorac Oncol. 2011; 6(8): 1379-91. PMid:21709590 http://dx.doi.org/10.1097/JTO.0b013e318220cb8e

[50] Socinski MA. The emerging role of biomarkers in advanced non-small-cell lung cancer. Clin Lung Cancer. 2010; 11(3): 149-59. PMid:20439190 http://dx.doi.org/10.3816/CLC.2010.n.019

[51] Park S, Ha SY, Cho HY, Chung DH, Kim NR, Hong J, Cho EK. Prognostic implications of hypoxia-inducible factor-1 $\alpha$ in epidermal growth factor receptor-negative non-small cell lung cancer. Lung Cancer. 2011; 72(1): 100-7. PMid:20822827 http://dx.doi.org/10.1016/j.lungcan.2010.08.005 
[52] Lu Y, Liang K, Li X, Fan Z. Responses of cancer cells with wild-type or tyrosine kinase domain-mutated epidermal growth factor receptor (EGFR) to EGFR-targeted therapy are linked to downregulation of hypoxia-inducible factor-1alpha. Mol Cancer. 2007; 6: 63. PMid:17931419 http://dx.doi.org/10.1186/1476-4598-6-63

[53] Swinson DE, O’Byrne KJ. Interactions between Hypoxia and Epidermal Growth Factor Receptor in Non-Small-Cell Lung Cancer. Clinical Lung Cancer. 2006; 7(4): 250-256. PMid:16512978 http://dx.doi.org/10.3816/CLC.2006.n.002

[54] Graves EE, Maity A, Le QT the Tumor Microenvironment in Non-Small Cell Lung Cancer Semin Radiat Oncol. 2010; 20(3): 156-163. PMid:20685578 http://dx.doi.org/10.1016/j.semradonc.2010.01.003

[55] Le Q, Chen E, Salim A. A comprehensive evaluation of tumor oxygenation and gene expression in patients with early stage non-small cell lung cancer. Presented at: 12th World Conference on Lung.

[56] Mylonis I, Chachami G, Paraskeva E, Simos G. Atypical CRM1-dependent nuclear export signal mediates regulation of hypoxia-inducible factor-1alpha by MAPK. J Biol Chem. 2008; 283(41): 27620-27627. PMid:18687685 http://dx.doi.org/10.1074/jbc.M803081200

[57] Mylonis I, Lakka A, Tsakalof A, Simos G. (2010). The dietary flavonoid kaempferol effectively inhibits HIF-1 activity and hepatoma cancer cell viability under hypoxic conditions. Biochem Biophys Res Commun. 2010; 398: 74-78. PMid:20558139 http://dx.doi.org/10.1016/j.bbrc.2010.06.038

[58] Ioannou M, Mylonis I, Kouvaras E, Papamichali R, Daponte A, Paraskeva E, Simos G, Koukoulis GK. Validated analysis of HIF-1alpha expression in cancer cells using a controlled and comparative immunoassay. Oncol Rep. 2010; 24(1): 161-9. PMid:20514457 http://dx.doi.org/10.3892/or_00000841 